\title{
Microbiological Assessment of Soil Planted with Cover Crops, and Soybean and Maize in Succession
}

\author{
Jaqueline Vanelli1, Edleusa Pereira Seidel2', José Renato Stangarlin², Marcos Cesar Mottin'1, \\ Pablo Wenderson Ribeiro Coutinho', Nicanor Pilarski Henquemeier ${ }^{1}$, Danielle Acco Cadorin', \\ Jucenei Fernando Frandaloso ${ }^{1}$, André Luiz Alves ${ }^{1}$ \\ ${ }^{1}$ State University of Western Parana (Unioeste), Marechal Candido Rondon, Paraná, Brazil \\ ${ }^{2}$ Center of Agrarian Sciences, State University of Western Parana (Unioeste), Marechal Candido Rondon, Paraná, Brazil \\ Email: jaqueline.vnll@gmail.com
}

How to cite this paper: Vanelli, J., Seidel, E.P., Stangarlin, J.R., Mottin, M.C., Coutinho, P.W.R., Henquemeier, N.P., Cadorin, D.A., Frandaloso, J.F. and Alves, A.L. (2018) Microbiological Assessment of Soil Planted with Cover Crops, and Soybean and Maize in Succession. American Journal of Plant Sciences, 9, 659-666. https://doi.org/10.4236/ajps.2018.94052

Received: January 17, 2018

Accepted: March 10, 2018

Published: March 13, 2018

Copyright (๑) 2018 by authors and Scientific Research Publishing Inc. This work is licensed under the Creative Commons Attribution International License (CC BY 4.0).

http://creativecommons.org/licenses/by/4.0/

\section{(c) (i) Open Access}

\begin{abstract}
This study aimed to assess the population density of nematodes and mycorrhizal soil fungi, in areas cultivated with oats, brachiaria, forage and white lupine, as well as in maize and soybean crops in succession, in order to generate a microbiological indicator of soil quality. In order to assess nematode and arbuscular mycorrhizal fungi (AMF) population densities, the experiment was performed in two stages: the first assessment was performed in the area where different cover crops were planted, in five seasons $(0,60,90,120,150$ days after sowing-DAS). In the second stage, soybean and maize crops in succession were assessed. According to the results, free-living nematodes and arbuscular mycorrhizal fungi population densities were not affected by the cover crop species used and, therefore, these can be grown prior to soybean and corn crops, without impact to free-living nematodes and AMF. The largest population of saprophyte nematodes and AMF occurred at 90 days. The cultivation of soybean and corn did not influence the number of free-living nematodes, but influenced the number of arbuscular mycorrhizal fungi. The highest numbers of mycorrhizal fungi Gigaspora margarita and Glomus macrocarpum were found in maize.
\end{abstract}

\section{Keywords}

Cover Crops, Microbial Biomass, Soil Management, Mycorrhizal Fungi

\section{Introduction}

The expansion of agriculture and its environmental impacts has led to the in- 
creased use of soil quality indicators, such as physical, chemical and biological properties. Scientific studies report that green manures are grown for the benefit of soils, ensuring the maintenance of soil organic constituents and improving its physicochemical properties, thus contributing to the control of plant pathogens and invasive plants, as well to erosion reduction [1].

Among the cover crops, species of the Fabaceae family are the most widely grown due to their capacity of nitrogen fixation, biomass production and their pivotal root system. These plants are able to absorb nutrients at deeper soil layers. Forage pea (Pisum sativum L.) has winter hardiness, with rapid initial growth, and grows well in a wide range of soil, improving soil fertility [2]. White lupine (Lupinus albus L.), which has well developed root system also deserves mention. This plant species has allelopathic substances that can inhibit the development of spontaneous vegetable species [3].

The Poaceae family is also composed of plants widely used in soil coverage, because they contribute with relatively high amounts of biomass and are characterized by a high $\mathrm{C} / \mathrm{N}$ ratio, providing soil coverage for a longer period of time [4]. They are resistant to water deficit, and the cost of their cultivation is lower. Moreover, their phenological cycle is shorter than that of the species of the $\mathrm{Fa}$ baceae family [1].

There have been a growing number of studies focusing on soil microbial activity, since microorganisms play an important role as nutrient regulators. They are responsible for the mineralization and nutrient cycling processes, as well as for the decomposition of organic matter, and also play a key role in soil genesis [5].

Nematodes are part of soil microfauna and are considered one of the most abundant and diversified organisms on the planet, with about 200 to 400 thousand species, of which only 12 thousand have been described [6]. One of the main functions of soil nematodes in the productive system is the release of nutrients, which are absorbed by the roots of plants [7]. While some soil nematode communities contribute to nutrient cycling, others are plant parasites and can cause heavy losses in annual food and fiber production.

Arbuscular mycorrhizal fungi (AMF) are important members of the soil-plant system, being vital for the sustainability of agriculture in tropical regions [8]. They have high abilities to absorb and translocate nutrients such as phosphorus [9]. The AMF increase plant resistance to root pathogen attack [10], and improve water absorption capacity. They also contribute to the accumulation of carbon stocks through microbial biomass and favor the stability of soil aggregates [6].

The diversification of plant residues from different types of crops can increase or reduce the composition of the microbial community, with impact on crop production [11] [12]. The objective of this study was to verify the population density of mycorrhizal fungi and nematodes in areas where oats (Avena strigosa), Brachiaria (Urochloa ruziziensis), forage pea (Pisum sativum) and white lu- 
pine (Lupinus albus) were used to verify that if the culture has influence on the population density of these microorganisms, crops were grown in succession to corn and soybean, with the purpose of generating a microbiological indicator of soil quality.

\section{Material and Methods}

The study was conducted at the Experimental Station, located at the geographic coordinates $24^{\circ} 40^{\prime} 32.66^{\prime \prime S}$ latitude and $54^{\circ} 16^{\prime} 50.46^{\prime \prime} \mathrm{W}$ longitude, 244 meters above sea level. The soil is classified as eutrophic Red Latosol, with very clayey texture [13]. According to Köppen climate classification, the climate of the region is humid subtropical (Cfa), with hot summers, average temperatures higher than $22^{\circ} \mathrm{C}$ and winters with average temperatures lower than $18^{\circ} \mathrm{C}$, with average annual precipitation of $1600-1800 \mathrm{~mm}$ [14].

The experiment was carried out in two stages. In the first stage, an experiment was carried out with different cover crops. Two species of the family Poaceae: black oats (Avena strigosa) and brachiaria (Urochloa ruziziensis) and two species of the family Fabaceae: forage grass (Pisum sativum) and white lupine ( $\mathrm{Cu}$ pinus albus). MFA and nematode populations were evaluated at 0, 60, 90, 120 and 150 days after sowing of cover crops, totaling five times. In the second stage, soybean and maize cultures were established in succession to cover crops, being evaluated at 60 days after their implantation.

The cover crops were mechanically implemented with a plot seeder, using 70 $\mathrm{kg} / \mathrm{ha}$ of black oat; $8 \mathrm{~kg} / \mathrm{ha}$ of brachiaria; $60 \mathrm{~kg} / \mathrm{ha}$ of forage pea and $50 \mathrm{~kg} / \mathrm{ha}$ of white lupine, without basic fertilization. Each plot was $5.40 \mathrm{~m}$ wide and $20.0 \mathrm{~m}$ long, totaling $108.0 \mathrm{~m}^{2}$. The line spacing was $0.20 \mathrm{~m}$ for black oat and brachiaria, and $0.40 \mathrm{~m}$ for forage pea and white lupine. Each split plot was $5.40 \mathrm{~m}$ wide and $10.0 \mathrm{~m}$ long; totaling $54.0 \mathrm{~m}^{2}, 0.50 \mathrm{~m}$ from the extremities and $0.45 \mathrm{~m}$ from the side of the split plots were discarded, totaling $40.50 \mathrm{~m}^{2}$. The management of these cover crops was performed 120 days after sowing, with the use of glyphosate at a dose of $3 \mathrm{~kg} / \mathrm{ha}$ acid equivalent.

The summer crops were mechanically implemented 25 days after the winter cover crops. Regarding the maize crop was used at a distance of $0.45 \mathrm{~m}$ between rows, with 4 seeds per linear meter, a population of approximately 88 thousand plants/ha. For soybean, it was used cultivar BMX Turbo RR BrasMax at a distance of $0.45 \mathrm{~m}$ between rows with 18 seeds per meter, approximately $80 \mathrm{~kg} / \mathrm{ha}$.

In order to identify and assess the population densities of nematodes and arbuscular mycorrhizal fungi, soil samples were collected at $0-0.10 \mathrm{~m}$ depth with an auger. 8 to 10 samples in each subplot (48 subplots, both for green manuring, and for soybean and corn in succession), of which a quantity of soil in a total sample of $300 \mathrm{~g}$ of soil was separated and performed the analyses. The samples were collected $0,60,90,120$ and 150 days after the sowing of the cover crops. On the other hand, the collections in the area with soybean and maize were made sixty days after sowing. Determination was made using decant- 
ing and wet-sieving technique associated with the flotation method using sucrose solution in $100 \mathrm{~cm}^{3}$ of soil [15]. After the extraction, quantification of nematodes and spores of mycorrhizal fungi was made with Peters' chambers, and identification was done with identification keys [16] [17]. The nematode population was counted (individuals number) and identified as free-living nematodes and plant-borne parasites [16], while arbuscular mycorrhizal fungi were classified according to the species [17]. Triplicate determinations were done to minimize the errors.

The results of population density of soil nematodes and mycorrhizal fungi were obtained by data processing according to the equation and were subjected to normality test, and homogeneity of variances, according to Lilliefors. When the analysis of variance was significant, regression analysis was performed using the statistical software Genes VS 20097.0 [18].

\section{Results and Discussion}

AMF spore extraction revealed the predominance of the Gigasporaceae families; genera Scutellospora heterogama and Gigaspora margarita, and family Glomeraceae, gender Glomus macrocarpum. According to the authors, these families have greater ability to adapt to various soils uses and managements. Most parasites identified were free-living nematodes. The results showed that cover crops (white lupine, forage pea, black oat and brachiaria) had no significant impact on the nematode and AMF population densities (Table 1) [19].

The amount and type of microorganisms depend on soil and climate conditions (acidity, amount of nutrients, moisture, oxygenation, temperature, organic matter). Therefore, it was expected that the introduction of different species of cover crops would favor the development of some species or genera. However, this was not observed in the present study.

On average, the number of free-living nematodes was 9.41 individuals per 100 $\mathrm{cm}^{3}$ of soil, which is below the values obtained by authors who found an initial population of 17.6 nematodes in $100 \mathrm{~g}$ of soil planted with velvet bean [20]. Also

Table 1. Average result for the number of nematodes (individuals number) and soil arbuscular mycorrhizal fungi (number of spores in $100 \mathrm{~cm}^{3}$ ) in soil under different cover crops.

\begin{tabular}{ccccc}
\hline Microorganisms and animals & $\begin{array}{r}\text { Free-living } \\
\text { nematodes }\end{array}$ & $\begin{array}{c}\text { Glomus } \\
\text { macrocarpum }\end{array}$ & $\begin{array}{c}\text { Scutellospora } \\
\text { heterogama }\end{array}$ & $\begin{array}{c}\text { Gigaspora } \\
\text { margarita }\end{array}$ \\
\hline White lupine & $10.29^{\mathrm{ns}}$ & $7.73^{\mathrm{ns}}$ & $14.84^{\mathrm{ns}}$ & $9.88^{\mathrm{ns}}$ \\
Oat & 9.14 & 5.74 & 14.50 & 9.58 \\
Brachiaria & 9.62 & 6.48 & 14.72 & 10.51 \\
Forage Pea & 8.60 & 6.14 & 14.58 & 9.84 \\
\hline
\end{tabular}

For normality tests and Anova, the results were transformed by $\sqrt{\mathrm{x}+0.5} \cdot{ }^{\mathrm{ns}}$ : there was no significance for any of the treatments, as indicated in the columns. 
no significant effect of green manure is found on the total number of individuals at a $0-0.10 \mathrm{~m}$ soil depth. The authors also observed a greater diversity of species, especially Acaulospora, Gigaspora, Scutellospora and Glomus under no-tillage system [21].

Statistical analysis showed a significant effect of the time of sampling on the population of Scutellospora heterogama: the largest population density of the species occurred 90 days after sowing (DAS) (Figures 1(a)-(d)).

Table 2 shows the number of individuals of AMF nematodes in $100 \mathrm{~cm}^{3}$ of soil assessed on maize and soybean crops 60 days after sowing, in succession to different cover crops. The mulches of cover crops were found to have no effect on the total number of individuals. Therefore, growing any green manure (white lupine, oat, brachiaria or pea) in the winter would have no effect (increase or decrease) on the populations of nematodes and AMF. The use of diverse species is recommended, as this allows a healthy balance in the rhizosphere. Frequent changes in soil management can cause balance disorders in the AMF community.

The largest number of Glomus macrocarpum (131.75) was observed in soil planted with maize, while in soybean the total number of these fungi was 75.51 ; Therefore, maize provided an increase of $57.31 \%$ in the number of individuals. Maize also favored the increase of Glomus margarita. The population was 417.33 in $100 \mathrm{~cm}^{3}$ of soil, while in soybean it was 217.21 , i.e. an increase of $50.84 \%$ (Figure 2). This increase can be explained by the deeper root system of maize that facilitates colonization by AMF, and the release of bioactive exudates by the roots, stimulating mycelial germination and growth [22].

The larger number of AMF individuals detected in the maize crop is extremely beneficial for the crop, as these fungi can promote a significant increase of the absorbing root surface area, increasing phosphorus absorption, in particular. Another benefit of this symbiosis is the exudation of hydrophobic glycoproteins called glomalins, which can increase soil aggregation. Extra-radicular hyphae also increase soil aggregation and stability [9].

Soybean grown in succession to brachiaria increased inorganic and organic phosphorus levels in the soil, and this increase was related to the greater mycorrhization of the plants [23].

Studies [24] found a higher mycorrhizal colonization in an area planted with maize in succession with Brachiaria, compared to soybean crop, being attributed to the lower root density in the soybean crop and the lower photosynthetic efficiency of this host plant.

Regarding the free-living nematodes and $S$. heterogama, there were no significant differences between soybean and maize crops. No scientific evidence of the performance of these microorganisms was found in the soil nematodes focused on soil ecological conditions [25].

The population of free-living nematodes and mycorrhizal fungi soil was not affected by green manure species (oat black, brachiaria, white lupine and forage pea). Therefore, the population of these micro-organisms is not a good indicator 


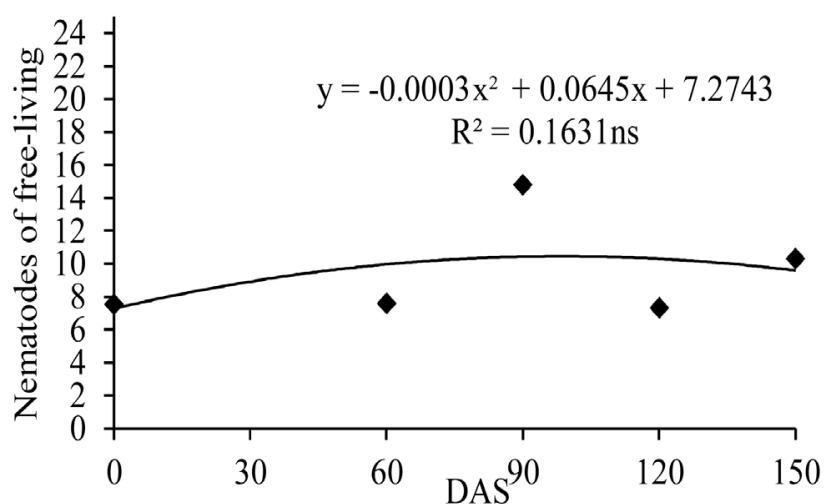

(a)

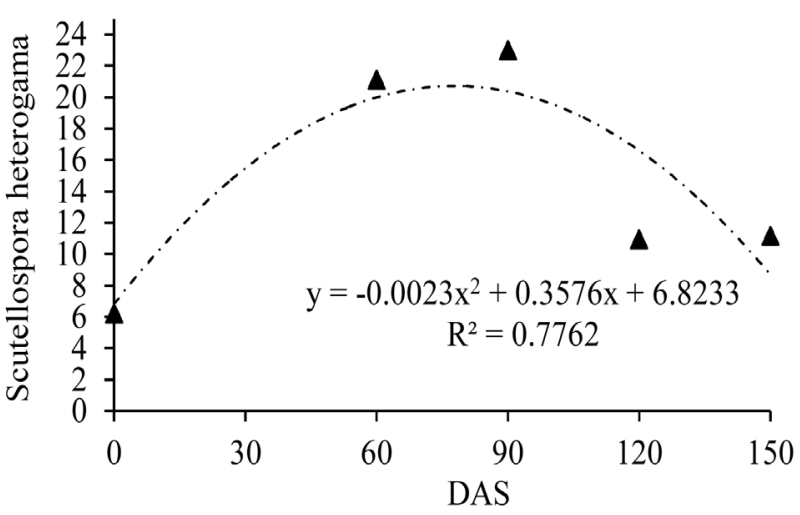

(c)

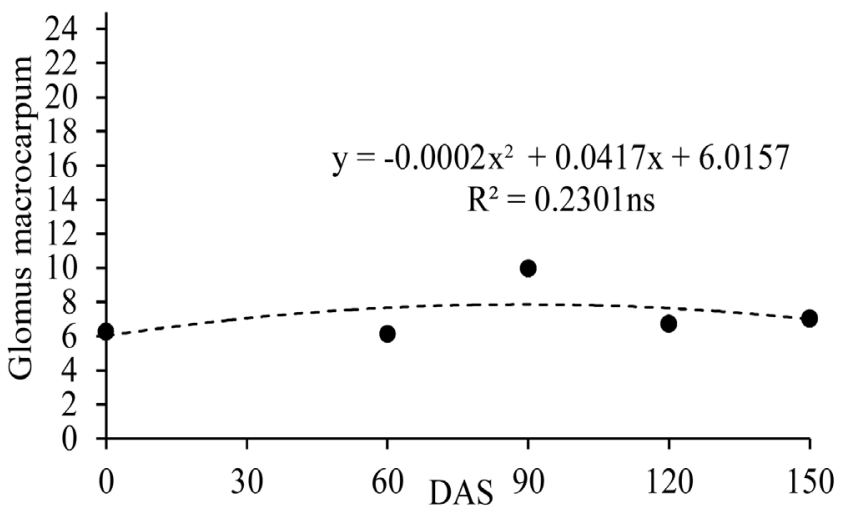

(b)

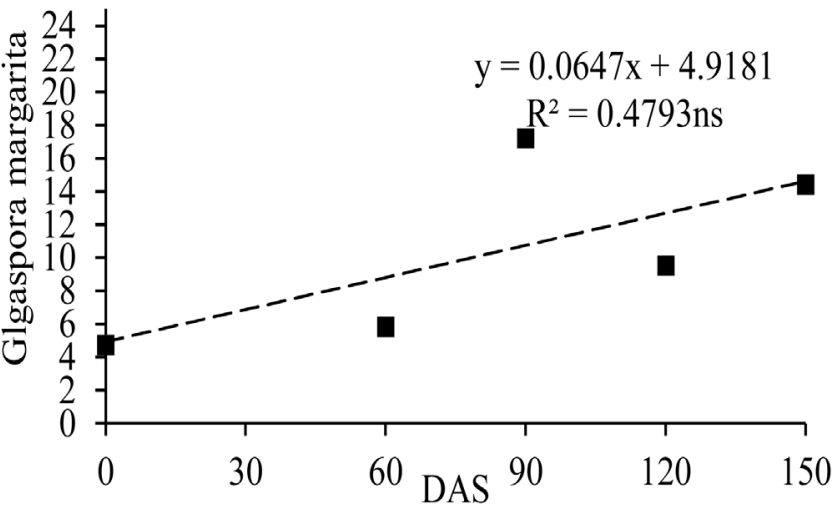

(d)

Figure 1. Average results for free-living nematodes and AMF Glomus macrocarpum, Scutellospora heterogama and Gigaspora margarita, at different sampling times, on cover crops (Brachiaria, black oat, white lupine and pea). For normality tests and Anova, the means were transformed by $\sqrt{\mathrm{x}+0.5} \cdot{ }^{\mathrm{ns}}$ : there was no significance for any of the treatments, as indicated in the Figure.

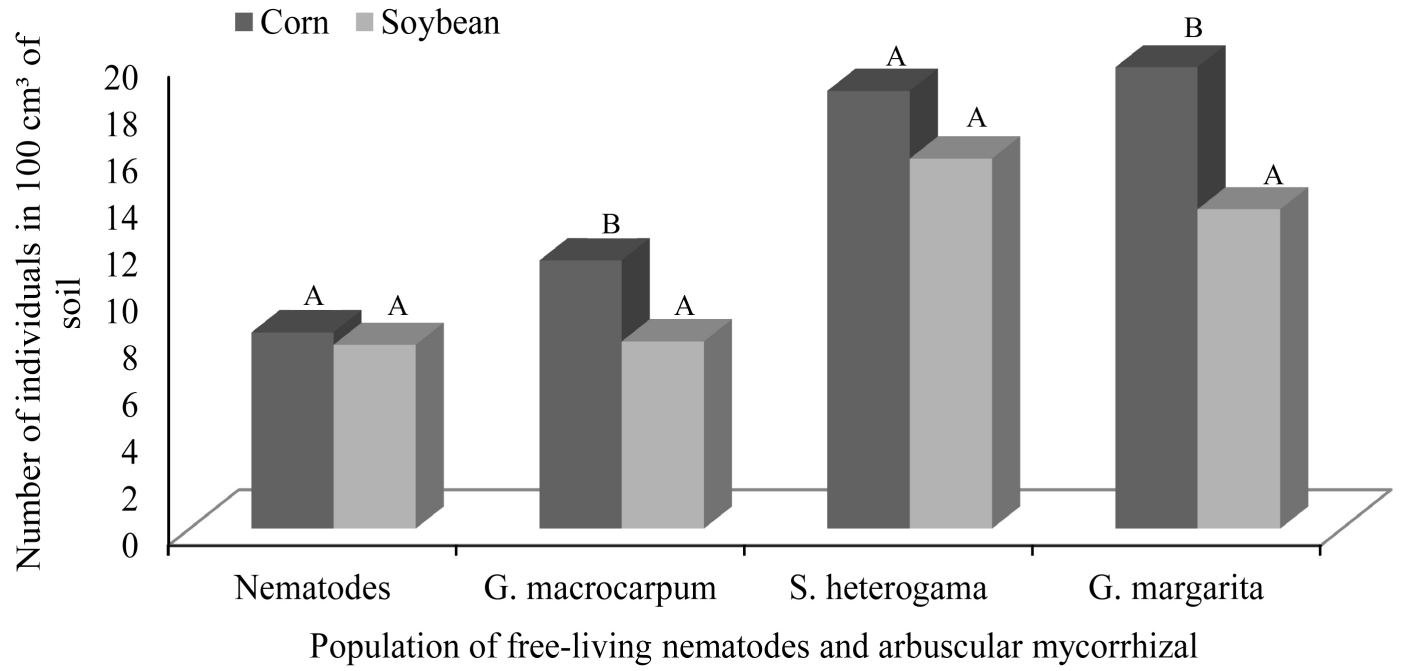

Figure 2. Average result for the population of free-living nematodes and arbuscular mycorrhizal fungi on summer soybean and corn crops in succession to winter green manures (Brachiaria, oat, forage pea and white lupine on $100 \mathrm{~cm}^{3}$ of soil). Equal letters do not differ by Tukey test $(\mathrm{p}>0.5)$. For normality tests and Anova, the means were transformed by $\sqrt{\mathrm{x}+0.5}$. 
Table 2. Average results for the number of nematodes and arbuscular mycorrhizal fungi in soil $\left(100 \mathrm{~cm}^{3}\right)$ planted with soybean and maize in succession to different cover crops.

\begin{tabular}{cccccc}
\hline $\begin{array}{c}\text { Summer } \\
\text { crops }\end{array}$ & Mulch & Nematodes & $\begin{array}{c}\text { Glomus } \\
\text { macrocarpum }\end{array}$ & $\begin{array}{c}\text { Scutellospora } \\
\text { heterogama }\end{array}$ & $\begin{array}{c}\text { Gigaspora } \\
\text { margarita }\end{array}$ \\
\hline \multirow{4}{*}{ Soybean } & White lupine & $6.21^{\mathrm{ns}}$ & $7.38^{\mathrm{ns}}$ & $15.35^{\mathrm{ns}}$ & $11.25^{\mathrm{ns}}$ \\
& Oat & 5.71 & 5.84 & 12.63 & 12.43 \\
& Brachiaria & 7.17 & 9.5 & 17.15 & 15.80 \\
& Forage Pea & 6.17 & 7.83 & 18.08 & 15.06 \\
& White lupine & $6.07^{\mathrm{ns}}$ & $11.37^{\mathrm{ns}}$ & $20.91^{\mathrm{ns}}$ & $23.62^{\mathrm{ns}}$ \\
& Oat & 9.27 & 10.56 & 18.66 & 18.63 \\
& Brachiaria & 7.81 & 9.04 & 17.58 & 18.78 \\
& Forage Pea & 9.28 & 9.33 & 17.63 & 17.82 \\
\hline
\end{tabular}

For normality tests and Anova, the means were transformed by $\sqrt{\mathrm{x}+0.5} \cdot{ }^{\mathrm{n}}$ : there was no significance for any of the treatments, as indicated in the columns.

of soil quality. The highest total number of Glomus macrocarpum and Gigaspora margarita was observed in the maize crop. The cultivation of soybean or corn did not influence the number of free life.

\section{References}

[1] Souza, C.M., Pires, F.R., Partelli, F.L. and Assis, R.L. (2013) Adubação verde e rotação de culturas. Ed. UFV, Viçosa, Minas Gerais.

[2] Fontaneli, R.S., Santos, H.P. and Fontaneli, R.S. (2012) Forrageiras para Integração Lavoura-Pecuária Floresta na Região Sul-Brasileira. 2nd Edition, Embrapa, Brasília.

[3] Corsato, M.J., Santorum, M., Leszczynski, R. and Fortes, A.M.T. (2008) Efeito alelopático do tremoço branco (Lupinus albus L.) sobre germinação e o crescimento inicial da alface, soja e picão preto. Revista Brasileira de Biociências, 6, 14-15.

[4] Calvo, C.L., Foloni, J.S.S. and Brancalião, S.R. (2010) Produtividade de fitomassa e relação $\mathrm{C} / \mathrm{N}$ de monocultivos e consórcios de guandu anão, milheto e sorgo em três épocas de corte. Bragantia, 69, 77-86. https://doi.org/10.1590/S0006-87052010000100011

[5] Moreira, F.M.S., Cares, J.E., Zanetti, R. and Sturmer, S. (2013) O ecossistema solo: Componentes, relações ecológicas e efeitos na produção vegetal. UFLA, Lavras.

[6] Siqueira, J.O., Souza, F.A., Cardoso, E.J.B.N. and Tsai, S.M. (2010) Micorrizas: 30 anos no Brasil. Ed. UFV, Lavras, Minas Gerais.

[7] Cares, J.E. and Huang, S.P. (2008) Comunidades de nematoides de solo sob diferentes sistemas na Amazônia e Cerrados Brasileiros. In: Moreira, F.M.S., Siqueira, J.O. and Brussaard, L., Eds., Biodiversidade do solo em ecossistemas brasileiros, Editora UFLA, 409-444.

[8] Berbara, R.L.L., Souza, F.A. and Fonseca, H.M.A.C. (2006) Fungos micorrízicos arbusculares: muito além da nutrição. In: Fernandes, M.S., Ed., Nutrição Mineral de Plantas, SBCS, Viçosa.

[9] Ramos, M.L.G., Konrad, M.L.F., Silva, D.E., Ribeiro Júnior, W.Q. and Batista, L.M.T. (2012) Diversidade de fungos micorrízicos e colonização radicular, em forrageiras solteiras e em consórcio com milho. Bioscience Journal, 28, 235-244.

[10] Guo, W., Zhaoa, R., Zhaoa, W., Fua, R., Guoa, J., Bia, N. and Zhangb, J. (2013) Ef- 
fects of Arbuscular Mycorrhizal Fungi on Maize (Zea mays L.) and Sorghum (Sorghum bicolor L. Moench) Grown in Rare Earth Elements of Mine Tailings. Applied Soil Ecology, 72, 85-92. https://doi.org/10.1016/j.apsoil.2013.06.001

[11] Pereira, A.A., Hungria, M., Franchini, J.C., Kaschuk, G., Chueire, L.M.O., Campo, R.J. and Torres, E. (2007) Variações qualitativas e quantitativas na microbiota do solo e na fixação biológica do nitrogênio sob diferentes manejos com soja. Revista Brasileira de Ciência do Solo, 31, 1397-1412. https://doi.org/10.1590/S0100-06832007000600017

[12] Zilli, J.E., Rumjanek, N.G., Xavier, G.R., Coutinho, H.L.C. and Neves, M.C.P. (2003) Diversidade microbiana como indicador de qualidade do solo. Cadernos de Ciência \& Tecnologia, 20, 391-411.

[13] Santos, H.G., et al. (2013) Sistema Brasileiro de Classificação de Solos.

[14] Caviglione, J.H., Kiihl, L.R.B., Caramori, P.H. and Oliveira, D. (2000) Cartas climáticas do Paraná. IAPAR, Londrina. http://www.iapar.br/modules/conteudo/conteudo.php?conteudo=677

[15] Jenkins, W. (1964) A Rapid Centrifugal-Flotation Technique for Separating Nematodes from Soil. Plant Disease Report, 48, 692.

[16] Mai, W.F. and Lyon, H.H. (1982) Pictorial Key to Genera of Plant-Parasitic Nematoides.

[17] Siqueira, J.O. and Franco, A.A. (1988) Biotecnologia do solo: Fundamentos e Perspectiva. MEC Ministério da Educação, ABEAS, Brasília; ESAL, FAEPE, Lavras.

[18] Cruz, C.D. (2006) Programa Genes: Biometria Editora UFV. Viçosa (MG).

[19] Ferreira, D.A., Carneiro, M.A.C. and Saggin Junior, O.J. (2012) Fungos Micorrízicos Arbusculares em um Latossolo Vermelho sob Manejos e Usos no Cerrado. Revista Brasileira de Ciencia do Solo, 36, 51-61. https://doi.org/10.1590/S0100-06832012000100006

[20] Oliveira, L.C., Stangarlin, J.R., Lana, M.C., Simon, D.N. and Zimmermann, A. (2012) Influência de adubações e manejo de adubo verde nos atributos biológicos de solo cultivado com alface (Lactuca sativa L.) em sistema de cultivo orgânico. Arquivos do Instituto Biológico, 79, 557-565. https://doi.org/10.1590/S1808-16572012000400013

[21] Angelini, G.A.R., Torres, J.L.R., Loss, A., Pereira, M.G. and Saggin Júnior, O.J. (2012) Colonização micorrízica, densidade de esporos e diversidade de fungos micorrízicos arbusculares em solo de Cerrado sob plantio direto e convencional. Semina: Ciências Agrárias, 33, 115-130. https://doi.org/10.5433/1679-0359.2012v33n1p115

[22] Siqueira, J.O. and Klauberg-filho, O. (2000) Micorrizas arbusculares: A pesquisa brasileira em perspectiva. In: Novais, R.F., Alvarez, V.H. and Schaefer, C.E.G.R., Eds., I Tópicos em ciências do solo, SBCS, Viçosa, 235-264.

[23] Merlin, A., Li He, Z. and Rosolem, C.A. (2013) Ruzigrass Affecting Soil-Phosphorus Availability. Pesquisa Agropecuária Brasileira, 48, 1583-1588. https://doi.org/10.1590/S0100-204X2013001200007

[24] Cordeiro, M.A.S., Paulino, H.B., Carneiro, M.A.C. and Saggin Júnior, O.J. (2005) Colonização e densidade de esporos de fungos micorrízicos em dois solos do cerrado sob diferentes sistemas de manejo. Pesquisa Agropecuária Tropical, 35, 147-153.

[25] Goulart, A.M.C. (2009) Análise de dados em estudos de diversidade de nematoides. Embrapa Cerrados, Documentos 251, Distrito Federal, Planaltina. 